\title{
Zpráva o pracovním semináři Únor 1948
}

Dne 19. února 2018 se konal v budově Akademie věd ČR pracovní seminář Únor 1948 s podtitulem Cesta k převratu a jeho důsledky, který organizoval Historický ústav Akademie věd ČR ve spolupráci s Ústavem pro studium totalitních režimů. Akce se uskutečnila pod záštitou místopředsedy Akademie věd ČR Pavla Barana. Cílem onoho setkání bylo nejen připomenutí výročí 70 let od únorových událostí, ale i analyzovat příčiny únorového převratu a jeho následky.

Po úvodním slovu statutárního zástupce ředitele Historického ústavu AV ČR Jana Němečka a ředitele Ústavu pro studium totalitních režimů Zdeňka Hazdry byl zahájen první okruh, jehož př́ispěvky se zabývaly tímto obdobím v právním a mezinárodním kontextu.

V prvním příspěvku se děkan Právnické fakulty UK Jan Kuklík věnoval ústavním aspektům únorového převratu 1948, poté následoval příspěvek Jindřicha Dejmka z Historického ústavu AV ČR zaměřený na mezinárodněpolitickou rovinu únorových událostí Komunistický převrat v Československu v kontextu akcelerující studené války v Evropě 1947-1948. Naopak do oblasti vnitropolitické směřoval Jiří Kocian z Ústavu pro soudobé dějiny AV ČR s tématem Osudové proměny českých politických stran. Sekci zakončila Zlatica Zudová-Lešková s tématem Medzi politickým taktizovaním, kompromisom a prevratom s podtitulem Jedinečné poučenie z dejín Slovenska od jesene 1947 do zimy 1948.

Druhá sekce se zabývala následky únorového převratu 1948. Marián Lóži z Ústavu pro studium totalitních režimů vystoupil s tématem Významy února 1948 pro regionální úroveň $K S \check{C}$. Reflexi těchto pro další osud Československa tak tragických událostí přednesl Jaroslav Šebek z Historického ústavu AV ČR, jenž se věnoval Transformaci akcentů národních tradic po roce 1948. Sekci završil Milan Bárta z Ústavu pro studium totalitních režimů s př́spěvkem na téma Lidové milice mezi bezpečností a stranou.

Závěrečná sekce se věnovala hospodářským aspektům tohoto citlivého tématu a dopadům převratu na československou ekonomiku, kam směřovaly př́íspěvky Jana Slavíčka z Historického ústavu AV ČR Únor 1948 jako predpoklad hluboké premény spotrebního družstevnictví v letech 1948-1952 a Jiřího Urbana z Ústavu pro studium totalitních režimů s Problémy a náladami na venkově v predvečer kolektivizace.

Formát pracovního semináře by vybrán záměrně, aby byl dostatečný prostor pro diskuzi po každém bloku příspěvků. Tento cíl byl splněn, po každém z okruhů se zapojila do debaty většina z prríchozích. Samotný pracovní seminář měl bohatou účast, účastnilo se ho více 
než 60 osob a část z nich zůstala i na závěrečné slovo doc. Němečka, který shrnul celé setkání a pozval všechny na číši vína.

doi: $10.14712 / 2464689 X .2018 .34$

Daniela Němečková 